Available online at http://jurnal.goretanpena.com/index.php/JSSR

\title{
SISTEM INFORMASI GEOGRAFIS PENYEBARAN COVID-19 DI KABUPATEN ASAHAN MENGGUNAKAN FRAMEWORK CODEIGNITER 4
}

\author{
Mardalius $^{1}$, Febri Dristyan ${ }^{2}$, Afdhal Syafnur ${ }^{3}$ \\ Sekolah Tinggi Manajemen Informatika dan Komputer Royal \\ e-mail: ${ }^{1}$ mardalius18@gmail.com
}

\begin{abstract}
The COVID-19 pandemic in Indonesia is part of the ongoing coronavirus disease pandemic 2019 (COVID-19) around the world. Covid-19 is a challenge in itself for each region, especially the country on how to effectively deal with it. Apart from strengthening the medical fleet, we also need accurate information regarding its distribution to determine which areas should be quarantined or not, especially the Asahan district. To find out information on the causes of covid-19, a system is needed to map a number of confirmed cases and are in the period of treatment or quarantine, the number of deaths due to this and the number of patients who have recovered, as well as areas where cases of Covid 19 infection were detected.
\end{abstract}

Keywords: gis; codeigniter; covid.

\begin{abstract}
Abstrak: Pandemi COVID-19 di Indonesia merupakan bagian dari pandemi penyakit koronavirus 2019 (COVID-19) yang sedang berlangsung di seluruh dunia. Covid-19 menjadi tantangan tersendiri bagi setiap wilayah terutama negara tentang bagaimana cara efektif menanggulanginya. Selain memperkuat armada medis, kita juga membutuhkan sebuah informasi akurat terkait penyebarannya untuk menentukan wilayah yang mana saja harus dikarantina atau tidak terutama wilayah kabupaten asahan. Untuk mengetahui informasi penyebaran covid-19 maka di butuhkanlah sebuah system untuk memetakan sejumlah kasus yang telah terkonfirmasi dan dalam masa perawatan atau karantina, jumlah kematian akibat wabah tersebut dan jumlah pasien yang telah sembuh, serta wilayah dimana kasus infeksi covid 19 terdeteksi.
\end{abstract}

Kata kunci: gis; codeigniter; covid.

\section{PENDAHULUAN}

Sistem Informasi Geografis (SIG) memiliki peran yang sangat luas dan dapat diaplikasikan pada berbagai fenomena alam yang terjadi. Tidak hanya persoalan penataan kota, lokasi tempat dan perencanaan wilayah, tetapi juga dapat memetakan sebaran penyakit karena infeksi virus seperti COVID-19 (corona virus diseases 2019), wabah yang tengah menghebohkan berbagai negara, tidak terkecuali Indonesia khususnya wilayah kabupaten asahan.

Geographic Information System (GIS) merupakan sistem informasi yang memanfaatkan data grafis yang terferensi secara spasial atau koordinat-koordinat geografi untuk mendapatkan informasi kewilayahan/lokasi diantaranya dalam bentuk peta digital. Melalui teknologi berbasis web GIS ini, peta sebaran COVID-19 dapat ditampilkan dengan lebih interaktif, efektif, dan informatif serta ditambahkan unsur edukatif, sehingga diharapkan bisa memberi informasi yeng dibutuhkan oleh masyarakat agar semakin peduli dengan bahaya COVID-19 serta selalu menerapkan protokol kesehatan dalam kesehariannya.

Komponen penting pada Sistem Informasi Geografis diantaranya adalah: (1) hardware (komputer) untuk penyimpanan dan pemprosesan data, (2) software yang dapat digunakan antara lain ArcView, ArcGis, dan QuantumGis; (3) Data berupa spasial (dapat berupa titik, garis, dan polygon) dan non-spasial 
Available online at http://jurnal.goretanpena.com/index.php/JSSR

(berupa informasi yang dimiliki objek dalam data spasial).

Melalui bantuan Sistem Informasi Geografis, wilayah yang terkena dampak virus Covid-19 dapat mudah terlihat dalam tampilan peta. Gambaran sebaran wilayah pasien positif terinfeksi virus, terkonfirmasi, kasus aktif dan meninggal disajikan dengan baik dalam peta. Peta sebaran covid-19 bisa dibuat secara statis maupun dinamis (real time), tergantung penyediaan data dan penginputannya.

Dalam peta penyebaran covid-19 sebaran ini dapat mendeskripsikan atau memberi informasi tingkat kerentanan disetiap kecamatan di kabupaten asahan daerah mana saja yang terpapar covid-19. Tingkat kerentanan dapat dibagi menjadi 5 kelas (misalnya sangat tinggi, tinggi, sedang, rendah, dan sangat rendah), 3 kelas (tinggi, sedang, dan rendah), atau 2 kelas (tinggi dan rendah). Hal ini disesuaikan dengan kebutuhan informasi yang akan disajikan.

\section{METODE}

Untuk dapat melakukan komunikasi dengan perangkat yang berbeda-beda di lingkungan web maka dibutuhkan sebuah web server. Karena standart dari geodata berbeda beda dan sangat spesifik maka pengembangan arsitektur system mengikuti arsitektur 'Client Server'.

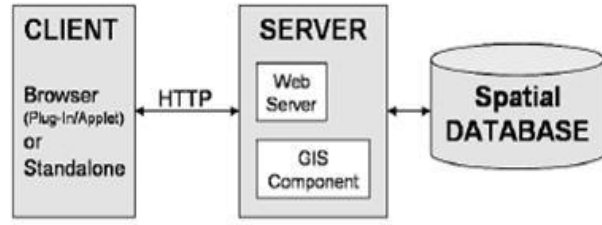

Gambar 1. Arsitektur WEB GIS

Pada gambar 1 menunjukan arsitektur minimum dari sebuah system Web GIS. Applikasi berada disisi client yang berkomunikasi dengan Server sebagai penyedia data melalui web Protokol seperti HTTP (Hyper Text Transfer Protocol), Server side GIS bertanggung jawab terhadap koneksi kepada database spasial seperti menterjemahkan query kedalam SQL dan membuat representasi yang diteruskan ke server. Dalam kenyataannya Server side Komponen GIS berupa software libraries yang menawarkan layanan khusus untuk analisis spasial pada data. Dalam membangun pemetaan covid-19 berbasis webGIS disini penulis menggunakan beberapa pendukung:

Pertama menggunakan framework CodeIgniter yaitu merupakan aplikasi sumber terbuka yang berupa kerangka kerja PHP dengan model MVC (Model, View, Controller) untuk membangun situs web dinamis dengan menggunakan PHP. CodeIgniter memudahkan pengembang web untuk membuat aplikasi web dengan cepat dan mudah dibandingkan dengan membuatnya dari awal. Model View Controller merupakan suatu konsep yang cukup populer dalam pembangunan aplikasi web, berawal pada bahasa pemrograman Small Talk, MVC memisahkan pengembangan aplikasi berdasarkan komponen utama yang membangun sebuah aplikasi seperti manipulasi data, antarmuka pengguna, dan bagian yang menjadi kontrol aplikasi. View, merupakan bagian yang menangani logika presentasi. Pada suatu aplikasi web bagian ini biasanya berupa berkas templat HTML, yang diatur oleh controller. View berfungsi untuk menerima dan merepresentasikan data kepada pengguna. Bagian ini tidak memiliki akses langsung terhadap bagian model. Model, biasanya berhubungan langsung dengan pangkalan data untuk memanipulasi data (insert, update, delete, search), menangani validasi dari bagian controller, tetapi tidak dapat berhubungan langsung dengan bagian view. Controller, merupakan bagian yang mengatur hubungan antara bagian model dan bagian view, controller berfungsi untuk menerima permintaan dan data dari pengguna kemudian menentukan apa yang akan diproses oleh aplikasi.

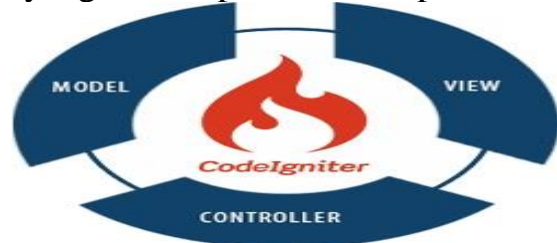

Gambar 2. Konsep MVC 
Available online at http://jurnal.goretanpena.com/index.php/JSSR

Kedua adalah menggunakan Leaflet Java Script atau di singkat (LaefletJS) merupakan sebiuah Library dari JavaScript yang bersifat Open Source atau Free. LeafletJS pertama kali dirilis oleh Vladimir Agafonkin pada tahun 2011. Library JavaScript ini khusus digunakan untuk membangun aplikasi pemetaan berbasis web, memdukung sebagian besar dari mobile dan desktop platform. Leaflet memungkinkan seorang tanpa latar belakang GIS (geographic Information System) mampu menampilkan peta web pada server publik dengan mudah. Terdapat banyak plugin yang dapat digunakan untuk menambahkan fitur-fitur tambahan pada peta web.

Ketiga adalam menggunakan file GEOJSON wilayah Kecamatan di Kabupaten Asahan. GeoJSON adalah format standar terbuka yang dirancang untuk merepresentasikan fitur geografis sederhana , bersama dengan atribut nonspasialnya. Ini didasarkan pada format JSON. Fitur-fiturnya termasuk titik (oleh karena itu alamat dan lokasi), string garis (oleh karena itu jalan, jalan raya dan batas), poligon (negara, provinsi, bidang tanah), dan koleksi multi-bagian dari jenis ini. Fitur GeoJSON tidak perlu hanya mewakili entitas dunia fisik; perutean seluler dan aplikasi navigasi, misalnya, mungkin menjelaskan cakupan layanan mereka menggunakan GeoJSON

\section{HASIL DAN PEMBAHASAN}

Penelitian ini menggunakan data covid-19 kabupaten asahan provinsi sumatera utara yang terdiri dari 25 kecamatan, data yang digunakan adalah data yang dikumpulkan dari bulan Januari 2020 Januari 2021 dengan data yang terdiri dari Terkonfirmasi, Kasus Aktif, Positf, Sembuh Dan Meninggal data utama berupa table dan dapat di lihat pa-da Tabel 1:
Tabel. Data Penyebaran Covid-19

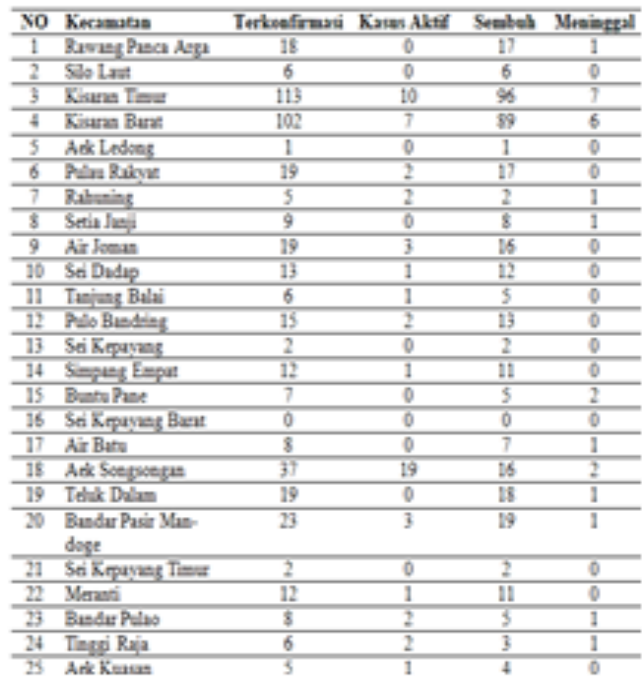

Dari data Tabel 1 maka dapat kita gunakan dan gambarkan dalam bentuk Peta coropleth sebagai metode representasi kartografis yang menggunakan pembedaan warna atau gradasi warna untuk mengisi polygon/kecamatan yang dipisahkan oleh isoline yang umum berupa daerah administratif. Berikut ini adalah peta choropleth penyebaran covid-19 didasarkan pada data table 1 jumlah penyebaran covid-19 setiap kecamatan di kabupaten asahan.

Pada pemetaan penyebaran berupa peta akan menampilkan informasi batas batas wilayah setiap kecamatan di kabupaten asahan dan menampilkan informasi warna tiap tiap wilayah dengan keterangan wilayah berwarna merah merupakan zona bahaya, warna orange dan kuning merupakan zona peringatan dan warna hijau merumpahan wilayah yang aman dari covid-19 selain itu saat user mengklik wilayah yang di inginkan maka akan menampilkan informasi berupa nama wilayah kecamatan, Terkonfirmasi, Kasus AKtif, Pasien Sembuh Dan Meninggal. Dengan adanya gambaran pemetaan seperti ini maka masyarakat akan lebih mudah mengetahui daerah daerah yang sedang terjangkit oleh covid-19. 
Available online at http://jurnal.goretanpena.com/index.php/JSSR

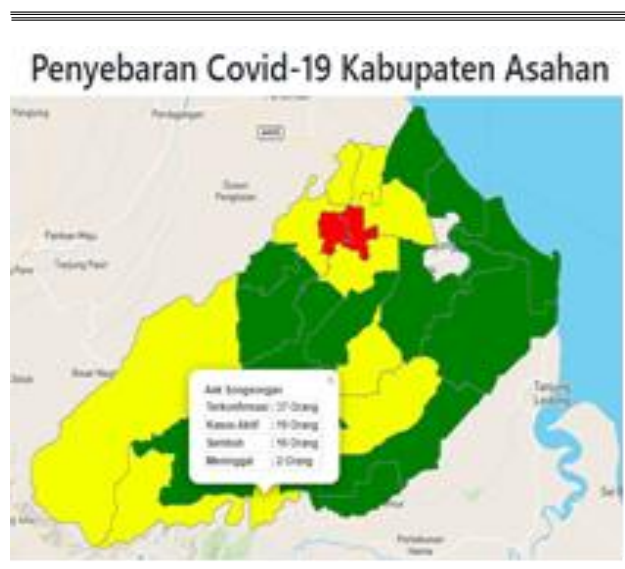

Gambar 3. Pemetaan Penyebaran Covid19

\section{Dashboard Utama}

Pada dashboard utama halaman website akan menginformasikan kepada pengunjung total dari kasus dari penyebaran seluruh wilayah kecamatan di kabupaten asahan yang terdiri dari total terkonfirmasi, kasus aktif, sembuh dan meninggal dunia.

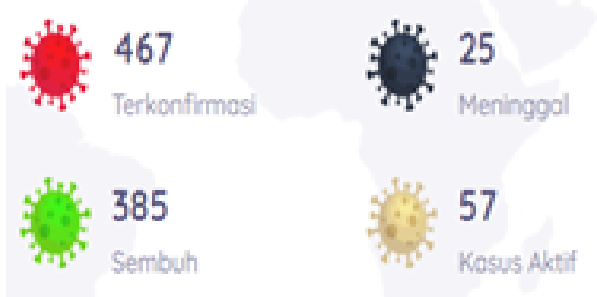

Gambar 4. Total Kasus Covid-19 Kab. Asahan

\section{SIMPULAN}

Pemetaan Penyebaran Covid-19 Berbasis Web GIS dapat diakses secara cepat, mudah dan memerlukan jaringan internet serta memberikan informasi mengenai pemetaan penyebaran Covid-19 di wilayah kabupaten asahan. Peta pada sistem mampu menampilkan informasi di setiap kecamatan berupa jumlah Terkonfirmasi, Kasus Aktif, Sembuh dan Meninggal. Penyebaran Covid-19 pada Sistem ini menggunakan fitur pol-ygon pada map untuk menandai wilayah (kecamatan) yang terinfeksi Covid-19. Sistem mampu memberikan report yang berupa grafik angka kasus penyebaran Covid-19 dan data yang ditampilkan sesuai dengan tanggal setiap hari. Sangat diharapkan pada penelitian selanjutnya dapat membantu menyempurnakan lagi kekurangan dari aplikasi ini.

\section{DAFTAR PUSTAKA}

Mulyadi, M. (2020). Partisipasi Masyarakat Dalam Penanganan Penyebaran Covid-19. Info Singkat, 12(8), 13-18.

Yulida, Y., \& Karim, M. A. (2020). Pemodelan Matematika Penyebaran COVID-19 di Provinsi Kalimantan Selatan. Media Bina Ilmiah, 14(10), 3257-3264.

Aulia, R. (2019). Pemetaan Lokasi Lkp Dan Bimbingan Belajar Di Kabupaten Asahan Berbasis Webgis. JurTI (Jurnal Teknologi Informasi), 3(2), 155-159.

Ristanto, F., Kaunang, W. P., \& Pandelaki, A. J. (2015). Pemetaan kasus demam berdarah dengue di Kabupaten Minahasa Utara. Jurnal Kedokteran Komunitas dan Tropik, 3(2).

Susanto, A., Kharis, A., \& Khotimah, T. (2016). Sistem informasi geografis pemetaan lahan pertanian dan komoditi hasil panen Kabupaten Kudus. Jurnal Informatika Ahmad Dahlan, 10(2), 103299.

Sultan, F. M. M., Jalaluddin, N. H., Radzi, H., Kasdan, J., \& Suhami, M. F. A. (2019). Dialek Melayu Perlis: Pemetaan Geodialek Beraplikasikan GIS (Perlis Malay Dialect: Mapping of Geodialect Using GIS). Akademika, 89(2).

Rahayu, Y., Muludi, K., \& Hijriani, A. (2016). Pemetaan Penyebaran 
Available online at http://jurnal.goretanpena.com/index.php/JSSR

dan Prediksi Jumlah Penduduk Menggunakan Model Geometrik di Wilayah Bandar Lampung Berbasis WebGIS. Journal of Information Systems Engineering and Business Intelligence, 2(2), 95.
Ferdiansyah, M. (2017). Sistem Informasi Geografis Pemetaan Klinik Bersalin Berbasis Web Gis (Studi Kasus: Kab. Pesawaran). Jurnal Cendikia, 14(2), 1-7. 